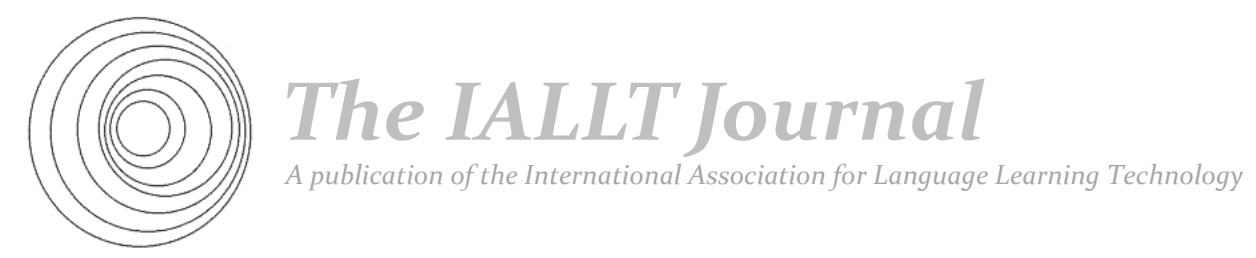

\title{
THE 'VirTUAL LANGUAGE LAB' VIRTUALLY PAINLESS, SIMPLy REAL
}

\author{
Lunden MacDonald \\ Metropolitan State College of Denver
}

\begin{abstract}
This paper discusses the technology that has inspired and guided the design of a 'virtual language center, ' within the context of a major urban college. Specifically, a number of mobile and cloud-based resources will be proposed and discussed such as: Asynchronous writing computermediated communication; Collaborative publishing; Textbook specific technological assistance; Video interface; Virtual realities and cyber-real estate; social networking tools; and communication tools that function in tandem with other technologies. The present paper provides a detailed assessment of the implementation of a virtual language learning center at one institution alongside suggestions for implementing a host of similar technologies at other schools. The paper argues that portable technology in the language classroom is particularly beneficial to the student and the instructor, and how it brings the language classroom and curriculum into the realm of best practices for 21 st-Century Learning.
\end{abstract}

\section{INTRODUCTION}

Since the middle of the $20^{\text {th }}$ century, the "language lab" has been a central component of foreign language instruction. From middle school to graduate school, students have dutifully trudged into a little carrel, put on their big, space-age earphones, and repeated catch-phrases meant to inscribe the vocabulary, grammar, and pronunciation of many foreign languages onto their eager brains. I personally remember saying "Ich bin Greta. Ich wohne in der Garten Strasse" no less than one thousand times during the year that I studied German in college. But despite the 
many hours I spent in the language lab, I did not emerge with a better knowledge of the inner workings of German , nor did my lab practice inspire me to continue my study of the language. The language lab was an integral component of my course, but I am not sure that it helped me to achieve all of my professor's instructional goals.

Still, when I became a language professor myself, I looked for ways to implement this de rigueur tool into my own courses. After all, it was how I "learned," shouldn't I be using a language lab to teach my own students? Plus, the days of the giant headphones were gone, and the modern language lab very often offered me a way to incorporate "cutting edge" technology into my instructionmaking me feel modern and cutting edge myself. So for many years I did incorporate lab time into each section that I taught, and I was so pleased when one of my students would come up to me with a smile on his face and say, with perfect pronunciation, “Yo soy Pablo. Vivo en la Calle Espoz y Mina." I felt fulfilled.

This changed when I arrived at my current job. I am an Assistant Professor of Spanish at the Metropolitan State College of Denver: a large $(24,000+)$ urban college in Denver, Colorado. I also serve as the lower-division Language Coordinator in the Spanish Program. We are a leader in language instruction in the state, teaching between 600 and 1,000 students in the 1010 and 1020 introductory levels in Spanish each semester, and about half that many in our second-year sequence. We work closely with Metro's Teacher Education Program, and will soon participate in the development of a Master's Program in that field. Our overall program is very strong, but we have one major problem: we have no language lab.

When I became aware of this issue, it stopped me in my tracks. The lab had been so ingrained in my methodology, it was like telling me that "Metro doesn't believe in textbooks" or "We don't have phones on campus"-it was, in short, a stumbling block both physical and mental that, to me, called for an immediate solution. If I couldn't send my students to a lab to practice, would I ever again hear that perfect "Yo soy Pablo"?

I began to investigate just why my school is missing this fundamental component of language instruction, and found that our problem has many causes. Metro State is unique in that we share a physical campus with two other postsecondary institutions, so finding an unused space for a dedicated language lab is virtually impossible. Colorado currently ranks last in the nation with regard to state funding of higher education, and the combination of this policy with the national budget crisis has conspired to cut Metro's operating budget by over 57\% for the upcoming academic year-so we are making cuts, not adding new projects. Even before the announcement of this budget reduction, the trend at our school has been to fund technology in the sciences and in business, while humanities departments have been left somewhat behind. When I asked administrators at my school about the possibility of establishing a language lab, I was met with amused smiles and little giggles-it just was not going to happen. 
But as is the case at most schools, performance expectations remain high at Metro, despite the lack of funding for capital projects and professional or instructional development. Metro's academic programs face the challenge of meeting college requirements of preeminent programming, curricular design, and student learning outcomes while limited by pre-modern financial support in the department and in the classroom.

So, in recent months I have spent a lot of time perseverating about space, "necessary" machines, instructional training, and other elements of a new language lab that I was certain was never going to get funded. My frustration was colossal. But in the course of my research, I stumbled upon a little gem of advice that redirected my efforts and offered me a potential response to my dilemma.

In a foundational article for the ACTFL volume on Technology-Enhanced Language Learning, Sharon Scinicariello (1997) wrote that, as we reconsider the definition of the language lab in the $21^{\text {st }}$ century, "Placing the language laboratory in its institutional context helps determine how the lab might best meet [foreign language learning] needs in cooperation with other units of the institution and which future needs the lab may be asked to serve” (p. 199). I had been focusing on creating a traditional language lab as an addition to $m y$ department, meant to enhance $m y$ language classes. Scinicariello's comment made me start thinking of the successful lab as part of a more global, institutional project-something that would integrate the methodological goals and pedagogical tools of foreign language learning into the college's mission and structural parameters. In my mind's eye, however, all I could see were rows of shiny computers and students beaming with joy as they practiced dictations and recorded their comments on mid-quality textbook illustrations. I had to start thinking out of the box.

\section{The Traditional LANGUAge LaB}

This type of innovative creativity does not just materialize-it requires a substantial review of the old, in order to bring out the new. With this in mind I went back to the basics, researching the history of the language lab in order to imagine its future. Roby's (2004) historical study suggests that the first mid-century language labs were "discipline-specific equipment configurations. The focus [was] on specialized audio installations" (p. 523). Various contemporary online dictionaries offer similar definitions of language labs as "room[s] designed for learning foreign languages and equipped with tape recorders, videocasette recorders, or computers connected to monitoring devices enabling the instructor to listen and speak to the students individually or as a group" (The Free Dictionary, April 20, 2009). Definitions on both ends of the chronological spectrum often speak to the "modernity" of the pedagogy supported by language labs (Oinas, 1960; Gaarder, 1960; Morton, 1960; Scinicariello, 1997; Roby, 2004; Wolz Verkler, 2004). 
The audio-lingual applications of the language lab were initially inspired by the late $19^{\text {th }}$-century study of phonetics (Sweet, 1877; Sievers, 1876; Techmer, Friedrich, 1880; Trautmann, 1884; Victor, 1884; MacMahon, 2001). Initially the focus of these labs was the accurate pronunciation of the foreign language being studied; production by native speakers and students in these labs was often analyzed by researchers in the field of linguistics in order to gain further insight into reproducible sounds and speech patterns. Throughout the course of the $20^{\text {th }}$ century, these labs evolved into more practical facilities that incorporated multidimensional media applications into the exercise of learning to speak a foreign language: "Labs of the period were principally audio installations, but movie, slide, and filmstrip projectors were sometimes present as well” (Roby, 2004, p. 524). Despite the evolution from an investigative tool to a practical tool of instruction, the emphasis of the language lab remained on the audio-lingual, though, and the interactivity quotient remained low.

This was due in part to the fact that language instruction was geared toward the achievement of military, not liberal arts, efforts. Following the Depression the two World Wars, the involvement of the military in the development of language labs and the accompanying technology came to be a major force in the installations that eventually made their way into academic foreign language teaching. Indeed, even the pedagogical approach was determined by the needs of the military. As Roby suggests, “...the development of the audiolingual method...stressed the listening and speaking skills more than reading and writing-[T]he priorities of prewar methods...relied much on small-group practice to develop the learners' aural and oral abilities...emphasis on mimicry of target language models (whether live or recorded) and the memorization of dialogues” (Roby, 2004, p. 525). These pedagogical goals were clearly introduced in order to develop language learning in the service of infield translation and interpretation.

Eventually, the "wow factor" of this modern linguistic technology, in combination with an emphasis on the audio-lingual aspect of the language lab, began to shape contemporary methodology in foreign language teaching. F. Rand Morton (1960) wrote that:

Today, more and more, the designation of 'language laboratory' implies not only the physical installation itself but, more important, the systematic, pedagogical exploitation of this installation: essentially, it has ceased to refer to a purely physical or architectural adjunct and has begun to imply an instructional system through which the existing equipment is pedagogically integrated with the language teaching program (p. 114-115).

The language lab started to become a cutting-edge focal point of foreign language instruction, and the equipment and space of the individual lab dictated the methods used to teach students. Heinich (1968) argued that, "for the first time, language teachers discovered that the mode and materials of instruction interact with 
instructional behavioral objectives and methods" (as cited in Roby, 2004, p. 50-51). "Language lab" became synonymous with a discipline-specific class of pedagogy, like "Skinner Box" meant Behaviorism, or "play” implied Constructivism.

As technology evolved during the second half of the $20^{\text {th }}$ century, so did its methodological application in the language lab. In particular, the increasing availability and popularity of personal computers in the 1980s occasioned a change in the purely audio-lingual methods used in early- to mid-century labs. New emphasis was placed on literacy skills. As Roby (2004) explains,

A further sign of the broadening of focus of language laboratories in the 1980s was the new attention given to reading and writing ...[E] arly labs were devoted solely to the "sound" skills of listening and speaking. Personal computers, which became popular in the 1980s, first made their entrance into the language laboratory because they could handle the "paper" skills of reading and writing ( $p .528)$.

But despite the allure of the new, multi-dimensional potential of the computerenhanced language lab, the paradigm of technology-driven methods remained static, and was caught in the realm of repetitive, non-communicative teaching and learning activity.

Ironically, this combination of methodological shift from emphasis on the audiolingual to focus on literacy and rapid technological evolution combined to determine the beginning of the end of the language lab (Roby 2004). The expense associated with maintaining and updating language lab equipment started to become prohibitive and, in the communication age, the appropriate curricular integration of the labs in language programs was no longer easily identified. Still, administrators of language programs felt compelled to offer lab space and time, despite their inability to pinpoint exactly what the labs were meant to be, or why their programs deemed them necessary.

Take the example of the lab at the University of Pennsylvania, originally established in 1986 as one of the forerunners of its kind. Over the years, the machinery became obsolete and financially difficult to replace. Fewer and fewer instructors used the language lab as a consistent venue for in-class instruction and out-of-class practice. Eventually the campus needed more computing space, so they installed regular computers and printers and turned the lab into a public computing facility for students.

Penn's faculty in foreign language instruction and the lab directors began to question their needs and to examine their methodologies. Their unanswered questions were later summarized, and they addressed the conundrum faced by many universities: “...do we need a traditional Language Lab facility? Probably not: and so it seemed to us foolish to even consider replacing the Language Lab with yet 
another lab that will be under-utilized as a teaching area. Saying this, does not mean that we don't require the facilities offered by a Language Lab, for we most certainly do"(Hiester and Abercrombie 1994). As the case of Penn illustrates, the need for a traditional language lab has diminished, but there still remains an unfulfilled requirement for the technological support of instructional practice and student use (Penn ended up setting up a lab that was connected to a central server and accessible through the school's local InterNet, called "PennNet." Information could be stored on this server and then downloaded by students).

I found myself asking the same questions as the lab directors from Penn. Specifically, what really was my need? As I stated above, I had the urge to use a lab facility-but why? Contemporary technology and increased student access to personal computing had replaced many of the functions of the traditional language lab-so why was I insisting that I needed one? Scinicariello's prescient comments from 1997 again seemed to speak to my thoughts. Imagining a nebulous technological future, Scinicariello (1997) wondered, "Will a language laboratory exist...? If all classrooms provide media support and all individual media use is distributed, the need for a lab that provides physical space for machines, materials, teachers, and students will end. If all information resources are managed through a central authority, the lab as media library may no longer be needed. The language lab will survive in the digital age only by redefining itself (p. 194-195). Taking these words to heart, and remembering what my research had proven to be outdated and ineffective in traditional labs, I began to consider just what this new definition would be.

\section{ASSESSING LocAL NEEDS}

It seemed that the answer to this question would be found in the resolution of the relationship between technology and methodology. I believed that, like the case at Penn demonstrated, our hands had become tied because we were letting technology dictate methods - and this approach was no longer working. I thought that a broad analysis of contemporary pedagogy would help me to reverse the directionality of this relationship and be able to better imagine how to let our methodological needs dictate our technological expression in foreign language teaching and learning.

I could not begin to figure out what pedagogy would be pertinent and what technological support I needed until I appropriately analyzed my "market. The Metropolitan State College of Denver is comprised of an amazingly diverse and talented student body. Many of our students are non-traditional, older men and women; about $40 \%$ of our population transfers in from local community colleges. Many of our students have special needs and require ADA consideration. Most of our students have children or other family responsibilities; almost all of our students work in addition to taking classes - some of them full time. The constraints of time and money — on the part of the student and on the part of the college — are a constant 
consideration. But perhaps what most impressively defines us is that our faculty students "want to be here" - they are all dedicated teachers and learners, eager to improve lives through education.

While in many ways Metro State is the epitome of the unique modern urban educational experience, we face the same administrative challenges and institutional requirements as other successful schools of higher education. We too are subject to various external accreditation and program reviews, and we must meet the objectives of internal strategic planning. In the data-driven culture of contemporary higher education, a vast majority of our funding depends on the confirmed success of our organizational and instructional efforts, so we at Metro State bow to the numbers and often measure our achievements with the coffee spoons of infinitesimal increases or decreases in percentages or statistics. In short, Metro State must achieve pedagogical preeminence while confronting the same institutional hurdles as any small, private college or large, research-driven undergraduate/graduate university.

On the department level, the Metro State Modern Languages Department also mimics the systemic and professional organization of many other schools. We employ a large and varied team of full-time, tenured or tenure-track professors as well as talented adjunct instructors who teach at all levels in our program. While we strive to maintain curricular quality and uniformity on the department level and in multi-section courses, individuality and freedom of instruction is preserved at all costs. We do not standardize instructional preeminence, and we do not squelch creativity for the sake of pedagogical norms.

Despite the diversity of our student body and faculty, there is one thing that levels the playing ground for students, instructors, and administrators at Metro: we are an edgy group of information-age teachers and learners, eager to use whatever tools we can find in order to achieve our educational goals. The majority of our students either own or have easy access to a personal computer or to public computing facilities; Metro State also has many computer labs for open student use, and our IT department is adept and efficient (if not well-funded). Technology has become a way for us to improve learning and living at Metro.

The above-mentioned needs and abilities of Metro State exemplify the paradigm of $21^{\text {st }}$-century learning and teaching. Recent research has indicated a need for a revision of traditional standards of pedagogy in order to accommodate the particular learning styles of $21^{\text {st }}$-century students, and to help them use education to acquire the skills they will need in order to function in contemporary society. Stevan Kalmon, the Director of the Council for $21^{\text {st }}$ Century Learning in Denver, Colorado, offers the following summary of the skills that the $21^{\text {st }}$-century learner must develop (Kalmon, S., personal communication, November 21, 2008):

1. Critical thinking and reasoning (e.g. problem solving, analysis, logic, cause/effect) 
2. Information literacy (e.g. knowledge acquisition, source discernment, systems management)

3. Collaboration (e.g. synergy, team resourcing, social skills, leadership)

4. Self-direction (e.g. adaptability, initiative, personal responsibility, work ethics, self-advocacy)

5. Invention (e.g. creativity, innovation, integration of ideas

The pedagogical approach that we adopt across the curriculum must facilitate the development of these skills; instructional methodology must therefore be revised as well in order to reflect current educational epistemology and to promote the achievement of these new student learning objectives.

The methods that will most efficiently support $21^{\text {st }}$-century epistemology can be classified under the umbrella of "Best Practice." The concept of Best Practice is widely applicable, although curricular specification pertinent to each discipline is possible. Zemelman, Daniels, and Hyde (2005) suggest in Best Practice: Today's Standards for Teaching \& Learning in America's Schools that "A more general, progressive educational paradigm is emerging across content boundaries and grade levels. This coherent philosophy and spirit is reaching across the curriculum and up through the grades" (p. 10). The "philosophy and spirit” of Best Practice calls for the elemental organization of pedagogical principles, assumptions, and theories into three "clusters" that determine effective methodological practice: Student-Centered schooling that is experiential, holistic, authentic, and challenging; Cognitive instruction that is simultaneously developmentally appropriate, constructivist, expressive, and reflective; and Social emphasis that is collaborative and democratic (Zemelman, Daniels, \& Hyde, 2005, p. 10-11). When we choose methodological applications with the goal of meeting $21^{\text {st }}$-century learning objectives, we must also consider their relevance to Best Practice philosophy and their potential for crosscurriculum, paradigmatic impact.

While Best Practice guidelines help to structure many instructional methods, the role of technology in the development of inter-disciplinary conceptual pedagogy for contemporary schools and students has been consistent and foundational. In 2008, the International Society for Technology in Education (ISTE) set forth a group of standards called the National Educational Technology Standards (NETS-T) and Performance Indicators for Teachers that were written in order to guide teachers in the development of tech-based materials and methodology that will support $21^{\text {st }}$ century learning goals. The ISTE states that "Effective teachers model and apply [these standards] as they design, implement, and assess learning experiences to engage students and improve learning; enrich professional practice; and provide positive models for students, colleagues, and the community" ${ }^{1}$. The five NETS-T standards for $21^{\text {st }}$-century technology use are:

\footnotetext{
${ }^{1}$ www.iste.org/Content/navigationMenu/NETS/ForTeachers/2000Standards/NETS_for_Teachers_2000.htm 
1. Facilitate and Inspire Student Learning and Creativity

2. Design and Develop Digital-Age Learning Experiences and Assessments

3. Model Digital-Age Work and Learning

4. Promote and Model Digital Citizenship and Responsibility

5. Engage in Professional Growth and Leadership

In the same way that technology helps make connections among the incredibly diverse population of students, teachers, and administrators at my school, technology also serves as a bridge between the skills objectives, pedagogy, and methods of $21^{\text {st }}$-century learning.

It was interesting for me to visualize the "big picture" of teaching and learning in the $21^{\text {st }}$ century, but as a foreign language professor I really needed to concentrate on what was happening in my own discipline as well. Professional societies and researchers within the discipline have identified both goals and methods of contemporary language teaching that reflect the overarching importance of $21^{\mathrm{st}}$ century skills, objectives, and global Best Practice methodology. These goals and methods are summarized in the American Council of Teachers of Foreign Languages (ACTFL) designation of the "Five Cs of Foreign Language Learning" 2 . These standards, established by ACTFL in 1999, speak to the educational end that we hope our foreign language learners obtain from our instructional means, and they serve as a guide as we determine the best methodological practice to reach these goals: Communication, Cultures, Connections, Comparisons, Communities. Keeping the Five Cs in mind as we develop $21^{\text {st }}$-century curriculum and practice will help us to place the appropriate disciplinary emphasis on teaching and learning in the foreign language classroom.

As I explained earlier, technology is consistently the common ground among all types of students, teachers, educational objectives, and instructional designs. When examining discipline-specific practice, therefore, it only makes sense to consider the particular technological tools that can be used in the service of foreign language teaching. Technology is a way that we can connect the goals of the college and our department to the needs of $21^{\text {st }}$-century learners and Best Practice methodologyand all under the rubric of discipline-specific instruction.

The unifying role of technology in foreign language learning has long been evident: in ACTFL's volume on Technology Enhanced Language Learning, Margaret Kassen (1997) writes that "Integration [of technology] entails not only the use of the computer in the classroom but also its use to support curriculum goals...[it can] help educators see the potential that technology offers in addressing the whole range of curricular objectives, from the low-level to the higher-level goals

${ }^{2}$ http://www.actfl.org/i4a/pages/index.cfm?pageid=3392 
of their discipline” (p. 266). Michael D. Bush (1997), one of the co-editors of this volume, supports this stance, state that "it makes sense to use technology in language-learning instruction for several reasons. Educational technology...

- is effective for delivering instruction;

- has unique pedagogical value;

- enables teachers to better address students' need for individualization;

- will help students better relate to life in the Information Age;

- can potentially inform the foreign language education profession about the nature of language and how it is learned" (p. 301).

Technology is a unifying force-but it is no longer unified. We have come so far since the reel-to-reel tape player that was the only machine of the "modern" language lab-we now have a menu of technological options to choose from that is vast and varied. Tools that fall under the global rubric of "technology" are no longer standardized or universally applicable. I began to see that what I was looking for in a language lab today could not be one machine, or even one location. This realization led me to my vision of a Virtual Language Lab.

\section{The ViRTUAL LANGUAgE LAB}

As I define it, a Virtual Language Lab is a fluid suite of assistive technological tools, determined by methodological goals and applications, that comprise a support system that helps me and my colleagues to meet college and departmental goals while working within the geographical and financial limitations of our school. The Virtual Language Lab is a portable, digital space that is liberated by the individuality of learners and teachers and finds expression in pluri-dimensional, multi-channel technological applications.

In the following section, I am going to give some practical examples of how I identified elements for my Virtual Language Lab that provide solutions to the many challenges I discussed above. My work does not represent a catalog of materials, nor does it discuss the creation of teaching tools. Instead, I would merely like to suggest an array of active and dynamic delivery portals. The list I discuss below is not by any means exhaustive nor particularly original; it does, however, offer suggestions about relevant and purpose-driven technology that can enhance L2 learning experiences.

\section{Web 2.0 Tools}

Almost all of the technological tools to be used in my VLL are Web 2.0-based. "Web 2.0" is one of those ambiguous terms that is frequently tossed around but seldom defined. In fact, the pluralistic nature of Web 2.0 technologies actually defy 
definition-but their categorization is not so hard. Michael Erskine and Alex McDaniel of the Metropolitan State College of Denver's Educational Technology Center describe Web 2.0 as a multi-channel, interactive, and communicative platform that pushes information and suggests inquiry. Web 2.0 is about repurposing old technologies in a graphic yet user-friendly interface-ubiquitous and usually free. It is about dynamism and openness: it is horizontal and scattered, and even chaotic in comparison to the vertical and linear character of Web 1.0. Most importantly, Web 2.0 is about how you use the web to interactively communicate. (M. Erskine and A. McDaniel, personal communication, February 17, 2009).

The communicative nature of Web 2.0 tools makes sense for a language-based project like mine in a rapidly changing and poorly funded technological world. The initial advent of the web itself gave rise to the possibility of development of materials for instructional support that were not at the financial and creative whim of constantly evolving hardware and software (Glatz 2001, p. 11). Today, the ubiquitous and free aspects of Web 2.0 tools offer an even better place to look for support in educational technology because they do not require the purchase or ownership of special machinery or parts. The majority of my discussion will be focused on these types of options.

\section{Asynchronous Writing Communication}

One of the first parts of my department that worked with the Virtual Language Lab concept was not an introductory sequence course, but rather our upper-division translation program in Spanish. Rote drills and flat activities were boring the students. Apart from group work in class using an overhead and a dry-erase marker, all translation activities were individually performed and isolated from the communicative aspects of simultaneous dual-language study. Wendy Gallagher, the instructor in charge of our Translation Program, was looking for a way to incorporate the $21^{\text {st }}$-century skills of critical thinking and reasoning into her students' translation activities, while simultaneously helping them to acquire the information literacy necessary to be competitive in the field of contemporary translation and interpretation. She wanted to inspire students to self-direct (another $21^{\text {st }}$-century skill), but at the same time she wanted to incorporate socially collaborative, communicative, and constructivist methods into her program.

The technological solution that she came up with falls under the heading of Asynchronous Writing Communication, and her specific response was to use Document Sharing to perform group translations. While similar objectives can be met by individual writing that is web-stored and later shared with the group-for example in the form of a blog-Wendy chose to set up a truly shared learning experience. By setting up an account for her class at Google Docs, she was able to post target-language material for the group to see, and the class worked together to perform the translation. As the class progressed through the translations, all changes to the original document were tracked, and discrepancies in style and approach were 
then discussed in face-to-face class meetings. This was a very simple platform for her students to use, with a relatively low learning curve. The design of this successful digital-age learning experience helped Wendy to solve many of her instructional challenges and the activity produced high-quality linguistic results.

The blog concept can be similarly useful, however-especially when managed with creativity and style. For example, At Princeton University, Jamie Rankin (senior lecturer in German) did a website project where the teachers and students put together a blog that helps with instructional methodology and student response. They have set up the site under the metaphor of a café, and the different things they can choose from are like the menu. Says Rankin, this website "provided cultural content for the students and the opportunity for the instructors to work with technology in meaningful pegagical [sic] [pedagogical] ways." (As cited in Edwards 2008).

\section{Collaborative Publishing}

Creating opportunities for students to use simple technology to work together from diverse geographical locations at disparate times solves many problems we face at Metro. But we still face the challenges of building interpersonal communities within our program and across cultures via foreign language communication. This is one of ACTFL's Five Cs-and community-building or constructivist learning activity is also an overarching objective of most higher-education general studies programs. Addressing these needs using asynchronous technological platforms can be easily done in the foreign language classroom by using collaborative publishing tools on the web.

One such tool that I personally have used with success is a Wiki. A Wiki is basically a collaborative web page. Students can add to the page by sharing written comments, inserting hyperlinks to other information, participating in asynchronous chats, and by adding video content. It is a free Web 2.0 tool that helps students move from the manipulation of information to the control of useable knowledge. A Wiki also encourages critical analysis and applied use of the target language in highly relevant situations, allowing students to increase understanding and incorporate language and culture into their internal configurations of knowledge (Reynard 2009). Most of my students were already familiar with Wikipedia and other types of group-design web sites, so it was easy to incorporate a Wiki into my language courses.

When I first used the Wiki, it was part of the redesign of an upper-division literature course. I wanted to make a shift from the Behaviorist to the Constructivist methodological paradigm, particularly in our discussions of literature and their historico-cultural relevance. I used the Wiki to create mini-groups within the class, and these groups created presentations on cultural and literary topics that they shared with their peers. Additionally, separate pages in the Wiki were created for daily 
comments on reading assignments — students asked questions of their own, and answered the questions of their peers on these pages. Students formed and added separate pages, links to external websites, embedded documents for sharing, and uploaded videos to the class project, and by the end of the term we had created a real product that was jointly owned by all the participants. This asynchronous interface was horizontally communicative, but also contributed to the full-scope social community building that reflects the Five Cs and $21^{\text {st }}$-century skills goals.

There are several emerging platforms that will offer similar benefits in collaborative technology, such as Drupal or the more sophisticated Pligus. A similar phenomena, but more technologically advanced, meta-data driven, and concentrated on incorporating prior or outside individual online production into a group or shared project, Drupal is “an open source content management platform... [that] supports a variety of websites ranging from personal weblogs to large community-driven websites" (www.drupal.org). A similar web-based resource, Pligus, expands upon the concept of collaborative communication by incorporating audio and video sharing capacity into an enhanced chat-room space (www.pligus.com). As fast as the ubiquitous Web 2.0 technology evolves, the concepts for internet collaboration among students are grown and implemented in ever-widening circles.

\section{Textbook Specific Technologies}

Many of these technological solutions are a bit more challenging to implement in the lower-division courses. Ironically, introductory levels are where departments see the most student and instructor traffic, and are therefore more in need of solutions to the challenges that they face. As the Course Coordinator for the lower-division program in my department, I am well aware of the issues we must consider in order to provide quality instruction to our students. We are a large program that offers many courses, and in the past we have suffered from vast differences in quality of instruction between sections. Metro State offers graduate degrees, but not in Modern Languages - and without graduate teaching assistants we often employ adjunct instructors who have become stagnant in their methods and who are resistant to change. This is not due to lack of desire or talent-but most of our adjuncts work at three or four different schools, and their schedules simply do not allow for the creation of new materials and methodologies or for continuous course redesign. On the student side, our lower-division courses are regularly filled with transfer students who are learning our school system in addition to a foreign language. Many of these students come unprepared for our courses and require extra help. We have so many students that we are frequently overcrowded, and our college is constantly asking us to develop online and hybrid courses that will resolve our issues of space and low faculty budgets. In short, our lower-division program is laden with challenges!

Technology can provide many responses to these challenges. Luckily, many publishing houses are now creating and marketing software suites that are webaccessible and compliment traditional text book packages - and that can respond to 
all of the above issues. Like a Web-CT or Blackboard course management system but specific to foreign language learning, many publishing houses are now creating language specific programs: Imagina for Spanish for Vista, Centro from McGrawHill, and MyLanguageLabs from Pearson are the current forerunners. I knew that I had to adopt some of these systems for our Virtual Language Lab. This type of commercial assistance allows for uniformity among multi-section courses via the establishment of a reproducible template, while still allowing for the maintenance of instructional individuality. The system itself allows instructors to access continuing methodological education by virtue of the varied exercises and embedded technology available within the program. Activities offered in-system are both synchronous and asynchronous, and respond to both behaviorist grammar drills and communicative speaking and listening situations. The machine-graded options cut down on the time investment required of adjuncts with multiple jobs. The uniform platform also allows transfer students to enter our school and immediately begin using a program that they might have seen elsewhere. These same students often benefit from immediate feedback and remediation provided in-system by commercial software, since the language programs at different schools are rarely on the same page in terms of content coverage.

Additionally, these systems assist with institutional funding and space issues by letting programs re-structure classes and at times re-classify them as hybrids. Many of these commercial systems also have further applications embedded in them, so you get a two-for-one deal. For example, we use MySpanishLab from Pearson-a technological support that effectively addresses the pedagogical needs and goals of instructors via best-practice use of technology, while meeting the varied learning needs of all students — and Wimba Pronto ("the only instant messaging system designed for education, [Wimba Pronto] enables students and teachers to uniquely collaborate and learn in an informal virtual venue") is embedded in-system at no additional cost to us. For us, adopting this type of software has dramatically improved our ability to deliver quality instruction. As Bob Hemmer, Executive Editor at Pearson Education and Program Manager of MyLanguageLabs explains (personal correspondence, March 3, 2009), "We should allow technology to do the things that technology does best, and free up the time to allow the instructors to do what they do best." These text-associate online learning systems serve just that purpose in the Virtual Language Lab.

\section{Video Interface}

Foreign language teachers have long faced the challenges of incorporating all four skills of reading, writing, listening, and speaking into daily lesson plans and overall course objectives. A student's ability to fully integrate the four areas may be compromised by factors as diverse as time constraints in a fast-paced class or weaknesses in one of the four skills that negatively affect the others. In particular, auditory skills represent huge hurdles for $\mathrm{L} 2$ learners, and the speed of native speech can often be prohibitive to comprehension. Additionally, the integration of 
authentic cultural materials across the skills can often prove to be extremely difficult — reading a flat passage about a painting from Spain, for example, is not the same as seeing it-even if it is accompanied by an infinitesimal photograph.

In the digital age, broadcast technology and video interface tools may address some of these challenges. Lawrence Glatz is a German Professor in my department and he has been using podcasts (digital media files syndicated via Internet) to assist his students with the above-mentioned challenges. By making content-specific podcasts available to his phonetics students, for example, he finds that they are able to listen to sound bytes again and again, reinforcing the audio in a way that text cannot achieve. He has discovered that this practice with podcasts allows him to raise the bar on listening and reading comprehension. He has also discovered that podcasts — and, in similar fashion, various pre-identified YouTube videos (YouTube is a video sharing website on which users can upload and share video clips, and view them in MPEG-4 format, www.youtube.com) or Audacity recordings (Audacity is free, open-source software for recording and editing sounds, http://audacity .sourceforge.net/).- - are a magnificent way to deliver cultural content: in his German Culture and Civilization course he assigns his students the task of listening to the German Chancellor's weekly podcast, found on the official government site. His mediation of this technology allows his students instant and authentic access to language and culture.

An even more multi-dimensional avenue for this type of methodological support is VoiceThread. VoiceThread is a "collaborative, multimedia slide show that holds images, documents, and videos and allows people to leave comments in 5 ways using voice (with a mic or a phone), text, audio file, or video (via a webcam)" (www.voicethread.com/about). Creating a VoiceThread page as a group can be of significant benefit, particularly in the area of cultural content and true communicative interface. VoiceThread combines receptive audio-visual aspects with productive oral and written commentary in a communicative and collaborative effort. It allows students to use language in a meaningful and contextually appropriate fashion. The visual media aspect in particular allows for the integration of authentic materials in a unique fashion. It is a holistic approach to target language, visual culture, auditory experience-basically an almost real-time cultural immersion while at home. This combination is an appropriate methodological manifestation of current pedagogical trends that strive to make discourse simultaneously “interpersonal, interpretive and presentational” (Wolz Verkler 2004, p. 458). My colleague Noah Giesel, a local high school Spanish teacher who works with me on program development and methodology, has been using VoiceThread to support the acquisition of TPR vocabulary. He uploaded a clip from the popular television show "Wipe Out" and asked his introductory-level students to create a discussion using active verbs around the video. For example, students commented, "he fell" or "he jumped." Noah has also uploaded video excerpts from targetlanguage movies and asked his students to create a VoiceThread page by writing subtitles for difference parts of the clip-now this is culture! 
The Virtual Language Lab...

\section{Virtual Realities \& Cyber-Real Estate}

The traditional audio-lingual focus of the old-time language lab was meant to increase a student's ability to accurately speak and, ultimately, to communicate. The audio-lingual pedagogy of those labs may be dated, but we still have an intense need to practice pronunciation and dialog in our language classes. This practice is often severely complicated by time constraints in the classroom, prohibitive student schedules that preclude out-of-class paired or group practice, and, in cases like mine, no language lab facility where students can go to engage in this type of conversation. Some of the current technologies that I have begun to include in my Virtual Language Lab offer many ways to meet the requirements of $21^{\text {st }}$-century learning and Best Practice methodology and resolve the prohibitive factors.

Second Life is one such technology and I have begun to incorporate it prominently in my Virtual Language Lab. Second Life is a free online virtual world imagined and created by its Residents...In Second Life, each person is represented by an avatar that in turn represents their chosen digital persona (www.secondlife.com). We first implemented Skype for videoconferencing and oral examinations in my department, but we are now expanding our technological vision into the virtual world. My college recently purchased an "island" in Second Life and has begun to develop the virtual real estate on the island with buildings that include museums, cafés, auditoriums, and concert halls. There are also virtual lecture halls and classroom and office space that can be used for delivering course presentations or for holding office hours. I can literally set up a Virtual Language Lab in the alternative universe of Second Life. This solves many issues of space on a crowded campus like ours, since a lecture can be delivered or office hours can be held remotely. Second Life also has capacity for audio chat as well as video and text messaging, so it solves a lot of ADA accessibility problems. Second Life is the perfect venue in which to hold online course meetings, and can be used to make a traditional course into a hybrid offering — something very important in the cuttingedge pedagogy of foreign and second language learning.

One of the most fantastic capabilities that Second Life has added to our Virtual Language Lab suite is the ability to leave our school's island and travel to other islands on which our students can practice the language they are learning. Either by voice chat or by text, students can experience authentic language communication around the world, from their homes or our school in Denver, Colorado. This is the ultimate in democratic learning environment, and it reinvents the incorporation of "study abroad" into a language program.

\section{Social Networking Tools}

For our digital native students, the Internet is a constant presence in every aspect of their lives. But this relationship is not uni-directional: our students are also continuously present on the web, and in fact have moved the majority of their 
interpersonal relationship maintenance to that venue. Networking sites like MySpace, Facebook, and Twitter have become the standard for social communication. Our students are extending that concept to their relationships with their teachers by researching them on Google or Facebook or LinkedIn before signing up for their class, or by checking out their scores on www.ratemyprofessor.com. We all, it seems, have a web presence. For awhile our students were requesting communication by cell phone, then email—but now if we want to reach our students and truly interact with them, the "market" demands social interface on one of the networking sites.

But this technology can be used in the service of learning in the foreign language classroom. Noah Giesel recently did a fun activity in one of his classes using Twitter. Noah recorded the Latin Grammys and showed them in his class. He hooked up a laptop to the LCD to show his Twitter account, and he had students call in to Twitter to "tweet" on the Grammy contestants. Although no one was talking out loud, the students were "talking” and communicating a lot in the target language. The activity was communicative as students read and responded to other people's comments. Using Twitter in a situation that replicated their normal, out-of-class social life made it seem that they were immersed in the culture-that the culture they were viewing was theirs.

This is an interesting example because often people fear that technology can create a disconnect between the digital native students and their digital immigrant professors - the different methods of interpersonal communication just don't match. But using this type of technology in my Virtual Language Lab has offered us the ability to provide the ultimate in student-centered activities that create enormous student buy-in. The personalization of Web 2.0 tools in the service of the student meets them on their path, and shows them the way to a better learning experience.

\section{Integrative Communication Devices}

The increased level of and dependence upon the integration of multi-media into the lives of students, exemplified by the prominence of Web 2.0 social networking tools today, has led researchers like Lawrence Glatz to classify $21^{\text {st }}$-century students as visually literate, entertainment-oriented, and technologically sophisticated (Glatz 2001, p. 3-4). These personality traits will naturally affect their learning styles. As teachers, we have always had to be aware of our students' methods of and capacity for knowledge acquisition - and this is no different in the digital age. And whereas before we altered instructional methodology to fit our students' learning styles, common logic dictates today that we use the technology that the students love to serve their educational needs. The applications of this concept in the language lab are nothing new: major thinkers in the field of pedagogy have been saying the same thing about technology for years. In the 1960 conference on language labs, the leader of the Behaviorist movement, B. F. Skinner, suggested as much in his article "Special Problems in Programming Language Instruction for Teaching Machines": 
that by using machines you could address different learning styles and individual pace while offering the feedback and positive reinforcement necessary to produce behavior change (considering here language learning as behavior) . (Skinner 1960, p. 167-184). Understanding this connection between successful learning and positive reinforcement led me to reconsider the use of cell phones and MP3 players in my foreign language classes.

It is practically impossible to find a student who does not own a cell phone or an MP3 device, and even more rare to find one who does not adore using whatever technological device they own. All my students love to text, they love to put glittery stickers on their Blackberries, they all have calluses on their thumbs. So I worked with Noah Giesel to conceive of ways that we could implement these technological tools into our curriculum. We came up with several "real language" learning activities that involved texting and creating voice files for shared downloading. More recently, Noah was awarded a grant from Quest to buy about 40 ipod touches to use daily in his classroom. He has wireless internet access, so he can perform his activities like the above-mentioned Twitter experience with ease. He has plans to incorporate real-time webquests or cultural scavenger hunts via Google Earth using these ipod touches - all with the end goal of providing an authentic cultural compliment to the literature and culture sections in his students' textbook. All of these suggestions provide ways to move beyond reading and fact-finding into real oral and written communication. Depending on the activity that is devised, these tools can encourage problem solving and higher level critical thinking through communication and implementation of technology.

\section{CONCLUSION}

Although Scinicariello's report on the "language labs of the future" played a foundational role in my development of the VLL, I must disagree with her on one point: in her article, Sciniciarello (1997) alludes to the possibility of a "virtual language lab" and stated that "Few schools will be willing or able to implement this or a similar version of the 'virtual' lab in the near future” (p. 195). A mere fourteen years after her publication, however, I believe that we are all ready, willing, and able to implement a Virtual Language Lab at our schools - from grammar school to university level. The future has arrived quicker than we expected, and I believe that now is the time to take the leap into consistent incorporation of technology-assisted foreign language teaching and learning.

As I advocate the implementation of a Virtual Language Lab, you might think that I am campaigning for the obliteration of my own job. Not true! In the past there has always been a designated "lab director" or central authority that ordered materials, organized maintenance and repairs in the lab, and investigated emerging technologies for future use. With a Virtual Language Lab, however, all this will be different: although I envision the organizational role of the course coordinator to 
remain similar, the concept of "management" will shift to the instructor of the course. Within certain parameters, each individual instructor will be able to pick and choose which materials and applications will match their methodological goals and needs - and also the individual needs of their particular group of students. Instead of acquiring, organizing, and distributing materials, the new "lab director" might train teachers to use new technologies, informing them of possibilities and serving as a researcher, disseminator, and inspiration.

Similarly, many people might fear that incorporating an environment like the VLL will take the place of the instructors. This fear is unfounded - and actually, the opposite is true. If anything, the role of the instructor as mediator of the technological tools being used to impart foreign language learning content is more important than ever. As opposed to the days when we put a textbook in an instructor's hands and said, "Go teach this," now the onus will be on the instructor to navigate their students through the myriad possibilities for the achievement of methodological goals and student learning objectives. In fact, our professors at Metro State have embraced this new role and expressed a sense of excitement and even relief at the refreshing ideas that technology is bringing to their sometimesstatic teaching. They are finding that the learning curve is not really all that steep, and that they really can do it.

This positive instructor reaction is mirrored in the enthusiastic buzz among their students. For the most part, students have been thrilled with our Virtual Language Lab. We have heard so many comments, ranging from compliments on our progressive methodology to expressions of the fun they are having with all the new and cutting-edge things we are doing in foreign language classes. On the other hand, some students have been less than excited about the sometimes-stressful learning curve for technology use. Good or bad, though, all of our students have admitted to a sense of empowerment for having learned the new technology, and they all recognize the importance of acquiring these skills in the digital age. There is a renewed sense of ownership and responsibility in our department since we began using the Virtual Language Lab, and it is pleasant to see more self-motivated, engaged students roaming our halls—and registering for our classes.

If you would like to consider implementing the idea of the Virtual Language Lab at your school, here are some things to keep in mind:

1. Identify your needs, both overarching and program-specific

2. Identify what you already have working for you in terms of technology at your school

3. Identify and assess your student population - who are they, what are they like, what do they like in terms of technology, what can they already do, what do they have to bring to the table

4. Speak with the IT people on your campus

5. Arrange for training or encourage instructors to self-educate

6. Be creative and have fun! 
As you gather information for your Virtual Language Lab, there are also a couple of caveats you should consider:

1. Copyright issues

2. Technology overload and learning curve issues

3. The experience and capability and expectations you have for adjunct faculty

4. The possibility of student resistance

5. The possibility of instructor resistance

One final suggestion: do not abandon the idea of a traditional language lab facility just because there is a lot of free stuff out there. Despite everything above, I am still pushing for a dedicated lab space for our department. Whether we designate it a Language Learning Center, a Language Lab, or a Technology Assisted Foreign Language Study Room, it would still be nice to have someplace to call our own, with a director that could be dedicated to keeping our entire department and all our students abreast of the most recent technology and the most contemporary pedagogy that will drive its use. Until then, the Virtual Language Laboratory is something functional for the overworked, underfunded, and perhaps under-prepared non-expert without a tech degree or huge quantities of expertise and time. It is a simple, practical solution to many challenges faced by our department, exciting and fun. 
MacDonald

\section{REFERENCES}

American Council on the Teaching of Foreign Languages (1999). National Standards for Foreign Language Education. Retrieved from http://www.actfl.org/i4a/pages/index.cfm?pageid=3392

Bush, M. D. (1997). Implementing Technology for Language Learning. In M. D. Bush and R. M. Terry, Eds. Technology-Enhanced Language Learning. In conjunction with the American Council on the Teaching of Foreign Languages (287-350). Lincolnwood, IL: National Textbook Company.

Brinton, D. M., Snow, M. A., and Wesche, M.B. (1989). Content-Based Second Language Instruction. Boston: Heinle and Heine Publishing.

Edwards, J. (2008, November 24). Das Café: Technology in the Language Classroom. It's Academic. A blog for and about Princeton University faculty use of technology for teaching and research. Retrieved from http://blogs.princeton.edu/itsacademic/2008/11/das cafe technology in the language_classroom.html

TheFreeDictionary. Language Lab. Retrieved from http://www.thefreedictionary .com/language=laboratory April 20, 2009.

Gaarder, A. B. (1960). Language Laboratory Techniques: The Teacher and the Language Laboratory. In F. J. Oinas, (Ed.) Language Teaching Today. A Report of the Language Laboratory Conference Held at Indiana University January 22-23 1960 (41-50). Indiana University: Research Center in Anthropology, Folklore, and Linguistics.

Glatz, L. F. (2001) Teacher Training Involving Technology. In G. Bräuer (Ed.), Pedagogy of Language Learning, Advances in Foreign and Second Language Pedagogy, Vol. 2. Atlanta: Ablex.

Heinich, R. (1968). The teacher in an instructional system. In F. G. Knirk \& J. W. Childs (Eds.), Instructional technology: A book of readings (pp. 45-60). New York: Holt.

Hiester, C. \& Abercrombie, J. (1994). Penn's Virtual Language Lab on the Internet. Retrieved from http://philae.sas.upenn.edu/VLLab.html

International Society for Technology in Education. (2008). National Educational Technology Standards (NETS-T) and Performance Indicators for Teachers. Retrieved from http://www.iste.org/standards/nets-for-teachers/nets-forteachers-2008.aspx 
Kassen, M. A. and Higgins, C. J. Meeting the Technology Challenge: Introducing Teachers to Language-Learning Technology. In M. D. Bush and R. M. Terry, Eds. Technology-Enhanced Language Learning. In conjunction with the American Council on the Teaching of Foreign Languages (263286). Lincolnwood, IL: National Textbook Company.

Lafford, P. A. and Lafford, B. A. (1997). Learning Language and Culture with Internet Technologies. In M. D. Bush and R. M. Terry, Eds. TechnologyEnhanced Language Learning. In conjunction with the American Council on the Teaching of Foreign Languages (215-262). Lincolnwood, IL: National Textbook Company.

MacMahon, M. K. C. Modern Language Instruction and Phonetics in the Later $19^{\text {th }}$ Century. In: Auroux, S., Koerner, E. F. K., Niederehe, H. J., Versteegh, K. (2001). History of the Language Sciences, Part 2: An International Handbook on the Evolution and Study of Language from the Beginnings to Present (1585-1595). Berlin \& New York: Walter de Gruyter.

Morton, F. R. (1960). The Language Laboratory as a Teaching Machine: Notes on the Mechanization of Language Learning. In F. J. Oinas, (Ed.) Language Teaching Today. A Report of the Language Laboratory Conference Held at Indiana University January 22-23 1960 (113-166). Indiana University: Research Center in Anthropology, Folklore, and Linguistics.

National Standards in Foreign Language Education Project (2006). Standards for Foreign Language Learning in the $21^{\text {st }}$ Century. Retrieved from http://www.globalteachinglearning.com/standars/5cs.shtml

Oinas, F. J. (Ed.) . (1960). Language Teaching Today. A Report of the Language Laboratory Conference Held at Indiana University January 22-23 1960. Indiana University: Research Center in Anthropology, Folklore, and Linguistics.

Parker, W. R. (1960). Foreward. In F. J. Oinas, (Ed.) Language Teaching Today. A Report of the Language Laboratory Conference Held at Indiana University January 22-23 1960 (v-viii). Indiana University: Research Center in Anthropology, Folklore, and Linguistics.

Reynard, R. (February 4, 2009). "Why Wikis?” Retrieved from http://campustechnology.com/Articles/2009/02/04/Why-Wikis.aspx?p=1

Roby, W. B. (2004). Technology in the Service of Foreign Language Learning: The Case of the Language Laboratory. In D. Jonassen (Ed.), Handbook of Research on Educational Communications and Technology, $2^{\text {nd }}$ Ed. (pp. 523-541). Mahwah, NJ: Lawrence Eribaum Associates 2004. 
Scinicariello, S. G. (1997). Uniting Teachers, Learners, and Machines: Language Laboratories and Other Choices. In M. D. Bush, and R. M. Terry, (Eds.), Technology-Enhanced Language Learning. In conjunction with the American Council on the Teaching of Foreign Languages (185-214). Lincolnwood, IL: National Textbook Company.

Sievers, Eduard (1876). Grundzüge der Phonetik: Zur Einführung in Das Studium Der Lautlehre Der Indogermanischen Sprachen. Leipzig: Breitkopf \& Härtil.

Skinner, B. F. (1960). Special Problems in Programming Language Instruction for Teaching Machines. In F. J. Oinas, (Ed.) Language Teaching Today. A Report of the Language Laboratory Conference Held at Indiana University January 22-23 1960 (167-184). Indiana University: Research Center in Anthropology, Folklore, and Linguistics.

Sweet, H. (1877) Handbook of Phonetics. London: MacMillan and Co.

Techmer, Friedrich (1880). Phonetik. I. Text und Anmerkungen. II. Atlas. Leipzig: Breitkopf \& Härtil.

Trautmann, M. (1884). Die Sprachlauk in Allgemeinen. Leipzig: Verlag Von Gustav Fock.

Victor, W. (1884). Elemente der Phonetik und Orthoepie des Deutschen, Englishen, und FranzUosischen. Leipzig: Heilbronn.

Wolz Verkler, K. (2004) Technology in the Foreign Language Classroom. Journal of Educational Media \& Library Sciences, 41 : 4 (June), 455-478.

Zemelman, S., Daniels, H., Hyde, A. (2005) Best Practice. Today's Standards for Teaching \& Learning in America's Schools. Portsmouth, NH: Heinemann. 
The Virtual Language Lab...

\section{About The Author}

Lunden MacDonald is an Assistant Professor of Spanish at the Metropolitan State College of Denver. She specializes in 18th- and 19th-Century Peninsular Literature and Enlightenment Studies. She also serves as the Coordinator for the lowerdivision sequence courses in the Modern Languages Department and researches effective and engaged teaching and learning in foreign language. 